\title{
PENGARUH MODEL WORD SQUARE BERBASIS SAINTIFIK TERHADAP HASIL BELAJAR TEMATIK SISWA MADRASAH IBTIDAIYAH KARANGDOWO
}

\author{
Zumrotus Sa'diyah ${ }^{1}$ \\ Habibatul Imamah ${ }^{2}$ \\ IAI Sunan Giri Bojonegoro \\ Zumrotus.Sadiyah@gmail.com
}

\begin{abstract}
Abstrak
Pengaruh Model pembelajaran Word Square berbasis saintifik terhadap hasil belajar siswa kelas IV MI. Tujuan penelitian ini adalah untuk mengetahui adanya pengaruh Model pembelajaran Word Square berbasis saintifik terhadap hasil belajar. Penelitian ini merupakan penelitian eksperimen metode penelitian True Experiment Design (eksperimen yang betul-betul) dengan jenis pretest-posttest control group design satu macam perlakuan,kelas. Subjek penelitian siswa kelas IV MI Karangdowo,sumberrejo, Bojonegoro.. Hasil penelitian menunjukan bahwa Model pembelajaran Word Square berbasis saintifik berpengaruh terhadap hasil belajar siwa kelas IV MI Karangdowo, Sumberrejo, Bojonegoro.
\end{abstract}

Kata Kunci:Word Square, Saintifik, Hasil Belajar, Tematik

\section{Abstract}

The influence of Word Square based scientific learning model on learning outcomes of fourth grade students of MI. The purpose of this study was to determine the influence of the scientific Word Square learning model on learning outcomes. This research is an experimental research method of True Experiment Design (a real experiment) with the type of pretest-posttest control group design one type of treatment. Research subject of fourth grade students of MI Karangdowo, sumberrejo, Bojonegoro .. The results of the study showed that the Word Square based scientific learning model had an effect on the learning outcomes of students in class IV MI Karangdowo, Sumberrejo, Bojonegoro

Keywords: Word Square, Saintifik, learning outcomes, Tematik

\section{PENDAHULUAN}

Pendidikan merupakan bagian yang penting dan tidak bisa dipisahkan dari kehidupan manusia. Pendidikan mempunyai peran penting dalam mengembangkan dan meningkatkan kualitas sumber daya manusia. Terutama untuk mengembangkan potensi 
yang dimiliki oleh peserta didik, supaya dapat berkembang secara optimal dan memiliki kepribadian dan akhlak yang baik. Pendidikan pada dasarnya merupakan suatu upaya pedagodis untuk mentrasfer sejumlah nilai yang dianut oleh masyarakat suatu bangsa kepada sejumlah subjek didik melalui proses pembelajaran. Dengan kata lain bahwa pendidikan dapat diartikan sebagai suatu hasil peradaban bangsa yang dikembangkan atas dasar pandangan hidup bangsa itu sendiri (nilai dan norma masyarakat) yang berfungsi sebagai filsafat atau sebagai cita-cita dan pernyataan tujuan pendidikannya.

Pendidikan adalah sarana utama yang perlu dikekola secara sistematis karena penidikan merupakan tonggak kemajuan sebuah bangsa. Pendidikan yang diselenggarakan pada satuan pendidikan, mulai dari pendidikan dasar sampai pendidikan tinggi, bahkan yang dilakukan dilembaga- lembaga nonformal dan informal seharusnya dapat menjadi landasan bagi pembentukan pribadi siswa, dan masyarakat pada umumnya. Namun kenyataannya mutu pendidikan, khususnya mutu output pendidikan masih rendah jika dibanding dengan output pendidikan dinegara lain. Rendahnya mutu pendidikan, memerlukan penanganan secara menyeluruh, karena dalam kehidupan suatu bangsa, pendidikan memegang peranan yang amat penting untuk menjamin kelangsungan hidup negara dan bangsa, juga merupakan wahana untuk meningkatkan dan mengembangkan kualitas sumber daya manusia.

Dalam kehidupan masyarakat modern, pendidikan diselenggarakan oleh sekolah. Sekolah berperan penting dalam perkembangan intelektual dan psikologi anak didik, karena di sekolah tempat berkumpulnya anak dari berbagai keluarga dan berasal dari masyarakat yang berbeda. Sekolah juga mempunyai peran membentuk kepribadian anak didik, sekolah akan menyalurkan dan mengembangkan bakat dan minat peserta didik sehingga menjadi seorang ahli yang berguna untuk dirinya dan untuk bangsanya. Sekolah sengaja dibangun dan dan diadakan sesuai dengan kebutuhan yang diperlukan oleh dan bangsa.

Pendidikan di sekolah tidak dapat dilepaskan dari proses pembelajaran dan interaksi antara guru dan peserta didik. Pembelajaran merupakan suatu proses yang rumit karena tidak sekedar menyerap informasi dari guru, tetapi juga melibatkan berbagai kegiatan dan tindakan yang harus dilakukan untuk mencapai hasil belajar yang baik. Seorang gurubukan hanya bertugas mengajar, tetapi juga guru diharapkan dapat membimbing, mengarahkan dan merangsang peserta didik agar lebih aktif dalam mengikuti pelajaran serta memacu siswa agar memperoleh hasil belajar yang baik (mengalami peningkatan). Untuk mencapai hal tersebut setiap guru dalam pembelajaran mampu menerapkan model, strategi dan metode pembelajaran yang mendukung tujuan pembelajaran dan sesuai dengan karakter peserta didik

Secaraumum pembelajaran yang telah dilakukan oleh seorang guru pada dasarnya sudah baik dimana peserta didik dapat mencapai KKM yang telah di tetapkan, tetapi bentuk pembelajaran yang terus menerus dilakukan belum tentu memberikan hasil yang sama dengan hasil yang sebelumnya. Maka diharapkan dalam proses pembelajaran seorang 
guru mampu mengkombinasikan satu modelpembelajaran dengan yang lain agar pembelajaran menjadi lebih variatif dari pembelajaran sebelumnya.

Guru merupakan orang yang paling berpengaruh dan berperan dalam meningkatkan sumber daya manusia yang berkualitas khususnya dalam proses belajar mengajar. Peran dan fungsi guru sebagai sebagai pendidik dan pengajar harus memiliki kestabilan emosi, cita-cita dan keinginan untuk mengembangkan potensi yang dimiliki oleh siswa, bersikap realitas, jujur dan terbuka, serta peka terhadap perkembangan, terutama inovasi pendidikan. Guru dituntut untuk memiliki empat kompetensi mengajar, diantaranya: kompetensi kepribadian, kompetensi sosial, kompetensi profesional, dan kompetensi pedagogik. Pada kompetensi pedagogik, guru dituntut untuk menerapkan berbagai pendekatan, strategi, metode, model, dan teknik pembelajaran yang mendidik secarakreatif dalam 8 mata pelajaran SD/MI. Untuk mencapai semua ini, guru harus memiliki pengetahuan yang luas, menguasai berbagai jenis dan praktik pendidikan, serta menguasai kurikulum.

kurikulum yang di gunakan saat ini adalah kurikulum 2013 dengan menggunakan pendekatan saintifik dengan suatu proses ilmiah yang mengembangkan pengetahuan, sikap, serta ketrampilan siswa dan pembelajaran pada kurikulum 2013 berbasis tematik dengan mengaitkan beberapa mata pelajaran sehingga dapat memberikan pengalaman yang bermakna bagi peserta didik. Prinsip pembelajaran tematik lebih menekankan pada konsep belajar sambil melakukan sesuatu (praktik secara langsung). Sehingga guru perlu mengemas atau merancang pengalaman belajar yang akan mempengaruhi aktivitas dan hasil belajar siswa. Hasil belajar merupakan cerminan tingkat keberhasilan atau pencapaian tujuan dari proses belajar yang telah dilaksanakan yang pada puncaknya diakhiri dengan suatu evaluasi ${ }^{1}$. Pembelajaran tematik dalam Kurikulum 2013 harus didesain dengan menarik yang dekat dengan lingkungan siswa agar tercipta suasana yang menyenangkan sehingga dapat meningkatkan semangat siswa dalam mengikuti pembelajaran. Pembelajaran harus direncanakan dengan baik sehingga siswa dapat menemukan konsep sendiri berdasarkan pengetahuan awal agar lebih bermakna ${ }^{2}$. proses pembelajaran yang aktif, kreatif, inovatif, efektif, dan menyenangkan dapat dilakukan oleh siswa yang disiapkan oleh pendidik melalui kegiatan-kegiatan yang menarik, menyenangkan untuk membangkitkan rasa ingin tahu, memotivasi siswa untuk berpikir kritis, dan menemukan hal-hal baru ${ }^{3}$.

Berdasarkan hasil penelitian yang telah dilakukan di MI karangdowo terdapat beberapa permasalahan dalam proses pembelajaran dengan kurikulum 2013 sebagai berikut: 1) proses pembelajaran tematik yang diterapkan masih terpisah-pisah (2) siswa cenderung takut untuk bertanya walaupun sebenarnya kurang memahami materi yang disampaikan guru, (3) pembelajaran cenderung mengacu pada Buku Guru dan Buku Siswa

${ }^{1}$ Soedijarto, Hasil Belajar Siswa (Rineka Cipta, Jakarta, 1997)

2 Dimyati dan Mujiono, Belajar Dan Pembelajaran, Rineka Cipta: Jakarta, 1999

${ }^{3}$ Dimyati dan Mujiono, Belajar Dan Pembelajaran, Rineka Cipta: Jakarta,1999 
meskipun terkadang tidak sesuai, (4) kesulitan memadukan antar muatan pelajaran dalam pembelajaran tematik, dan (5) siswa cenderung memperoleh materi dari aktivitas membaca dan mendengar belum sampai aktivitas melakukan.

Permasalahan yang telah diuraikan diatas berdampak pada perolehan hasil belajar siswa yang masih ada di bawah KKM. Hasil belajar siswa dihasilkan dari proses pembelajaran. Pembelajaran adalah hubungan antara siswa dan guru didalam kelas untuk menghasilkan interaksi antara siswa dengan guru dalam proses belajar. Sehingga menciptakan proses pembelajaran yang optimal untuk meningkatkan hasil belajar siswa, untuk itu pendidik harus menggunakan model pembelajaran yang tepat.

Berdasarkan kondisi permasalahan diatas maka perlu adanya suatu inovasi baru dalam pembelajaran, salah satu inovasi tersebut adalah dengan menggunakan model Word Square berbasis saintifik pada pembelajaran tematik. Model Word Square adalah Model pembelajaran model pembelajaran kooperatif yang memadukan kemampuan menjawab pertanyaan dengan kejelian dalam mencocokkan jawaban pada kotak-kotak jawaban. Model tersebut hampir sama dengan teka-teki silang, perbedaannya yaitu jawaban sudah ada dan disamarkan dengan menambahkan kotak tambahan berisi huruf sebagai pengecoh. Tujuan huruf pengecoh bukan untuk mempersulit siswa, namun melatih sikap teliti kritis. ${ }^{4}$

Model pembelajaran adalah kerangka konseptual yang melukiskan prosedur sistematik dalam mengorganisasikan pengalaman belajar untuk mencapai tujuan belajar tertentu, berfungsi sebagai pedoman bagi perancang pembelajaran dan para guru dalam merancang serta melaksanakan pembelajaran. Oleh karena itu, hal-hal yang harus diperhatikan ketika memilih model pembelajaran antara lain yaitu materi pelajaran, jam pelajaran, tingkat perkembangan kognitif siswa, lingkungan belajar dan fasilitas penunjang yang tersedia, sehingga tujuan pembelajaran yang telah ditetapkan dapat tercapai.

Model pembelajaran adalah suatu perencanaan atau suatu pola yang digunakan sebagai pedoman dalam merencanakan pembelajaran di suatu kelas atau pembelajaran dalam tutorial model pembelajaran ialah suatu rencana atau pola yang dapat digunakan untuk membentuk kurikulum (rencana pembelajaran jangka panjang), merancang bahanbahan pembelajaran, dan membimbing pelajaran dikelas atau yang lain. Model pembelajaran mengacu pada pendekatan pembelajaran yang akan digunakan, termasuk didalamnya tujuan-tujuan pengajaran, tahap-tahap kegiatan pembelajaran, lingkungan pembelajaran dan pengelolaan kelas.

Model berfungsi sebagai pedoman bagi perancang pengajaran serta para guru dalam merencanakan dan melaksanakan aktivitas belajar mengajar. Strategi, metode, teknik, pendekatan, dan model memiliki hubungan yang saling terkait, karena berpatokan pada penentuan tujuan pembelajaran, pemilihan strategi, teknik, dan perumusan tujuan yang kemudian diimplementasikan ke dalam metode yang relevan selama proses

\footnotetext{
${ }^{4}$ Depdiknas. 2010. Materi Sosialisasi Kurikulum 2013 Depdiknas:Jakarta 2013.
} 
pembelajaran dengan menggunakan model pembelajaran yang dapat menarik perhatian sehingga pembelajaran berjalan dengan baik. model pembelajaran merupakan suatu rancangan atau konsep yangdapat digunakan oleh pendidik dalam proses pembelajaran.

Model pembelajaran meliputi rancangan mengenai proses pembelajaran yang dilaksanakan dari tahap awal hingga tahap akhir. Dengan menggunakanmodel pembelajaran diharapkan proses pembelajaran menjadi terarahsehingga tujuan dari pembelajaran dapat tercapai dengan baik. Model pembelajaran memiliki ciri-ciri sebagai berikut:

a.Berdasarkan teori pendidikan dan teori belajar dari para ahlitertentu.

b.Mempunyai misi atau tujuan pendidikan tertentu.

c.Dapat dijadikan pedoman untuk perbaikan kegiatan belajarmengajar.

d.Memiliki urutan langkah-langkah pembelajaran.

e.Memiliki dampak sebagai akibat penerapan model pembelajaran.

f.Membuat persiapan mengajar (desain instruksional) denganpedoman model pembelajaran yang dipilihnya

Berdasarkan pemaparan tersebut, dapat disimpulkan bahwa model pembelajaran pada dasarnya merupakan bentuk pola pembelajaran yang tergambar dari awal sampai akhir yang disajikan secara khas oleh guru, dimana didalamnya melibatkan startegi, teknik, pendekatan dan metode untuk mencapai suatu tujuan pembelajaran dan keberhasilan peserta didik.

Model pembelajaran Word Square merupakan pengembangan dari metode ceramah dan termasuk salah satu model pembelajaran inovatif yang dapat memberikan inovasi pada proses pembelajaran. Model pembelajaran ini terdapat nuansa bermain didalamnya. Hornby mengungkapkan bahwa word square adalah sejumlah kata yang disusun sehingga kata-kata tersebut dapat dibaca kedepan dan ke belakang. Model ini meminta peserta didik lebih aktif dalam proses pembelajaran, peserta didik harus menemukan jawaban yang benar dalam kotak kotak jawaban ${ }^{5}$. Alasan dipilihnya model pembelajaran word square, karena model ini melibatkan peran aktif siswa secara langsung di dalam kelas serta melatih disiplin siswa, Dalam pelaksanaannya, terjadi interaksi komunikatif antara guru dan siswa karena siswa terlibat aktif dalam pembelajaran.

Model ini juga merupakan model yang memadukan kemampuan menjawab pertanyaan dengan kejelian dalam mencocokkan jawaban pada kotak-kotak jawaban mirip seperti mengisi "Teka-Teki Silang" tetapi bedanya jawabannya sudah ada namun disamarkan dengan menambahkan kotak tambahan dengan sembarang huruf/angka penyamar atau pengecoh. ${ }^{6}$ Model pembelajaran word square syarat dengan permainan

\footnotetext{
${ }^{5}$ Eko Puji Dianawati, Penggunaan Media Word Square Dalam Memotivasi Belajar Siswa Smk, Jurnal Ilmiah Guru "COPE": No. 01/Tahun XVII/Mei 2013, h.23.

${ }^{6}$ Eko Puji Dianawati, Penggunaan Media Word Square Dalam Memotivasi Belajar Siswa Smk, Jurnal Ilmiah Guru "COPE”: No. 01/Tahun XVII/Mei 2013, h.23.
} 
yang menggunakan kertas sebagai media, keuntungannya adalah meningkatkan kecerdasan anak dalam olah huruf menjadi kata yang berserak dalam satu bingkai kotak, dimana peserta didik diminta untuk menghubungkan huruf dengan cepat, baik secara menurun atau mendatar. Word square juga melatih siswa dalam berpikir kreatif untuk menemukan hubungan-hubungan baru antara berbagai hal.

Model pembelajaran word square berisi pertanyaan-pertanyaan penting suatu konsep atau sub konsep. Setelah itu peserta didik berdiskusi untuk mendapatkan jawaban dan menemukannya pada kotak-kotak word square. Pada akhir pembelajaran, peserta didik menyimpulkan materi bahasan yang telah didiskusikan dengan demikian peserta didik memperoleh pengalaman belajar yang berarti. Model word square merupakan pembelajaran kooperatif yang menuntut kemandirian peserta didik dalam menemukan kata-kata dalam kotak kata. Menggunakan model pembelajaran ini di kelas akan mengurangi ketergantungan siswa terhadap guru sehingga pembelajaran tidak hanya berpusat dari guru. Sehingga dalam proses pembeajaran daam kelas menjadi lebih efektif dan menyenangkan.

Adapun Kelebihan Model Pembelajaran Word Square, diantaranya:

a. Kegiatan tersebut mampu mendorong peserta didik untuk memahami materi.

b. Melatih untuk disiplin.Yang dimaksud dengan melatih disiplin disini adalah dapatmelatihketetapanpeserta didik dalam menjawab pertanyaan.Karena jawaban dari pertanyaan tersebut telah disiapkan olehpendidik.

c. Dapat melatih sikap teliti dan kritis. Dengan menggunakan model pembelajaran word square makadapat melatih peserta didik untuk teliti karena dalam mencari jawaban peserta didik harus teliti. Untuk dapat menjawab pertanyaan peserta didik harus memahami terlebih dahulu mengenai topik yang sedang dibahas. Peserta didik yang memahami materi mereka pasti selalu ingin tahu lebih dalam mengenai pembahasan tersebut. Rasa ingin tahu yang mendalam itulah yang membuat peserta didik menjadi kritis.

d. Merangsang pesertadidikuntuk berpikir efektif. Dalam mencari jawaban peserta didik harus berpikir efektif yaitu dapat mencari jawaban mana yang paling tepat.

e. Baik untuk menguji hasil belajar yang berhubungan de-ngan pengetahuan tentang istilah;

f. Melatih ketelitian dan ketepatan dalam menjawab dan men-cari jawaban

Word square merupakan salah satu dari sekian banyak model pembelajaran yang dapat dipergunakan pendidik dalam mencapai tujuan pembelajaran. Dengan menggunakan model pembelajaran ini, dalam kegiatan belajar mengajar pendidik mengimplementasikannya dengan bantuan lembar kegiatan atau lembar kerja sebagai alat untuk mengukur tingkat pemahaman peserta didik terhadap materi pelajaran yang telah diajarkan. Instrumen utama model pembelajaran ini adalah lembar kegiatan atau lembar 
kerja berupa pertanyaan yang perlu dicari jawabannya pada susunan huruf acak yang terdapat pada kolom yang telah disediakan

\section{METODE PENELITIAN}

penelitian ini menggunakan metode eksperimen True Experiment Design (eksperimen yang betul-betul) dengan jenis pretest-posttest control group design satu macam perlakuan. Menurut Arikunto (2013: 210), metode penelitian True Experiment Design (eksperimen yang betul-betul) dengan jenis pretest-posttest control group design satu macam perlakuan, sebelum dimulai perlakuan kedua kelompok diberi tes awal atau pretest untuk mengukur kondisi awal (01). Selanjutnya pada kelompok eksperimen diberi perlakuan $(\mathrm{X})$ dan pada kelompok pembanding tidak diberi. Setelah selesai perlakuan, kedua kelompok diberi tes lagi sebagai posttest (02). Dalam penelitian ini, yang menjadi populasi adalah seluruh siswa MI Karangdowo kecamatan Sumberrejo kabupaten Bojonegoro. Sampel adalah bagian (anggota) dari populasi yang diambil secara benar ${ }^{7}$, Sampel penelitian ini yakni seluruh siswa kelas IV MI Karangdowo kecamatan Sumberrejo kabupaten Bojonegoro. Teknik sampling merupakan teknik pengambilan sampel. Dalam penelitian ini, peneliti menggunakan teknik sampling nonprobability sampling yaitu sampling jenuh ${ }^{8}$.

\section{HASIL DAN PEMBAHASAN}

Hasil belajar berasal dari kata hasil dan belajar. Hasil belajar merupakan hasil yang dicapai oleh peserta didik berupa angka atau skor setelah mengerjakan tes yang diberikan oleh guru. Dapat dikatakan hasil belajar adalah hasil yang telah dicapai oleh siswa setelah mengikuti ujian. Hasil belajar menunjukkan kemampuan siswa yang sebenarnya yang telah mengalami proses pembelajaran, jadi dengan adanya hasil belajar, orang dapat mengetahui seberapa jauh siswa dapat menguasai materi pelajaran yang telah dijelaskan oleh guru.

Hasil belajar adalah pola-pola perbuatan, nilai-nilai, pengertian-pengertian, sikapsikap, apresiasi dan ketrampilan.Jadi hasil belajar adalah hasil dari belajar dalam bentuk angka atau nilai yang merupakan pedoman bagi hasil belajar siswa berdasarkan hasil evaluasi. Hasil belajar merupakan perubahan berupa kecakapan fisik, mental, intelektual yang berproses dari kegiatan belajar baik di jenjang pendidikan formal seperti sekolah dan di jenjang pendidikan non formal seperti dilingkup keluarga dan masyarakat yang akan digunakan dalam kegiatan sehari-hari baik didalam sekolah maupun bermasyarakat ${ }^{9}$.Hasil

\footnotetext{
${ }^{7}$ Arikunto, Suharsimi. Dasar-dasar Evaluasi Pendidikan. Jakarta: PT. Bumi Aksara.2013

${ }^{8}$ Arikunto, Suharsimi.. Dasar-dasar Evaluasi Pendidikan. Jakarta: PT. Bumi Aksara.2013

${ }^{9}$ Soedijarto.. Hasil Belajar Siswa. Jakarta: Rineka Cipta. 1997
} 
belajar pada penelitian ini terbatas berupa kecakapan intelektual saja yang diukur dari hasil tes formatif.

Hasil belajar merupakan suatu parameter yang dapat digunakan dalam menentukan berhasil atau tidaknya tujuan pendidikan yang telah dilaksanakan dalam satuan pendidikan. Dalam sistem pendidikan nasional rumusan tujuan pendidikan baik kurikulum maupun tujuan instruksional menggunakan klasifikasi hasil belajar dari Benyamin Bloom yang terdiri dari ranah kognitif, afektif dan psikomotorik.

Ranah kognitif adalah suatu ranah kemampuan berfikir tentang fakta-fakta sfesifik, pola prosedural, dan konsep-konsep dalam mengembangkan pengetahuan dan keterampilan intelektual.Bloom merumuskan taksonomi pembelajaran khususnya dalam ranh kognitif mulai dari keterampilanberfikir tingkat rendah sampai pada keterampilan berfikir tinggi. Ranah kognitif Bloom terdiri dari enam jenis perilaku yaitu pengetahuan, pemahaman, penerapan, analisis, sintetis dan evaluasi. Ranah afektif adalah ranah yang berkaitan dengan sikap dan nilai. Ranah afektif mencakup watak perilaku seperti perasaan, minat, sikap, emosi, dan nilai. Ciri-ciri hasil belajara afektif akan tampak pada peserta didikdalam berbagai tingkah laku. Ranah psikomotor merupakan ranah yang berkaitan dengna keterampilan / skill atau kemapuan bertindak setelah seseorang menerima pengalaman belajar. Ranah psikomotor sangant berhubungan dengan aktivitas fisik.

Berdasarkan analisis data yang telah dihitung dari uji t satu pihak, dapat diketahui bahwa hipotesisnya yaitu terdapat pengaruh model pembelajaran Word Square berbasis saintifik terhadap hasil belajar tematik pada siswa kelas IV thitung $>$ ttabel $=3,100816112$ $>1,72$. Data perhitungan uji t satu pihak juga diperkuat dengan hasil perhitungan uji $n$ gain, dengan hasil $n$-gain 0.42 di kelas kontrol dan 0.55 di kelas eksperimen.

Hasil diatas menunjukkan bahwa model pembelajaran Word Square berbasis saintifik memberikan pengaruh terhadap hasil belajar peserta didik, karena model pembelajaran Word Square berbasis saintifik adalah model pembelajaran yang menekankan pada keaktifan peserta didik selama proses pembelajaran. Hasil uji t juga diperkuat oleh ketuntasan belajar kelas eksperimen yakni sebanyak 20 peserta didik mencapai ketuntasan belajar dengan presentase ketuntasan 95\% (19 siswa) dan nilai ratarata 83,75 . Sedangkan pada kelas kontrol hanya terdapat 14 peserta didik yang tuntas hasil belajarnya dengan presentase ketuntasan $70 \%$ dan nilai rata-rata 76 .

Adanya perbedaan presentase ketuntasan dan nilai rata-rata antara kelas eksperimen dan kelas kontrol disimpulan bahwa pembelajaran dengan model pembelajaran Word Square berbasis saintifik berpengaruh untuk meningkatkan hasil belajar tematik siswa kelas IV MI Karangdowo. model pembelajaran Word Square berbasis saintifik di kelas eksperimen menjadikan siswa lebih aktif, antusias dalam pembelajaran karena tidak hanya duduk memperhatikan guru ceramah dan mencatat materi yang disampaikan. Tetapi siswa juga berdiskusi, menyampaikan pendapat, mempertahankan pendapat serta bekerja sama dengan teman kelompoknya. Keberhasilan pembelajaran eksperimen tidak muncul begitu saja. Namun banyak factor yang mendukung keberhasilan tersebut, salah satu faktor 
yang mendukung keberhasilan itu adalah sekolah yang memadai dengan segala fasilitas yang diperlukan. Selain itu, Keberhasilan tersebut tidak lepas dari model pembelajaran Word Square berbasis saintifik yang telah diterapakan.

Diterapkannya model pembelajaran Word Square memberikan lebih banyak waktu kepada siswa untuk berdiskusi, bertukar pendapat dan bekerja sama dengan siswa lain, sehingga lebih percaya diri dan lebih mudah memahami materi yang disampaikan oleh guru. Sebelum mengerjakan soal evaluasi siswa juga dilatih dengan cara diberi kuis, sehingga hal ini membuat siswa semakin siap untuk mengerjakan soal evaluasi. Rata-rata nilai tes sebelum perlakuan pada kelas eksperimen sebesar 70,25 dengan 9 siswa (45\%) yang dintayatakan tuntas dan 11 siswa (55\%) dinyatakan tidak tuntas. Setelah itu menggunakan model pembelajaran Word Square berbasis saintifik diperoleh nilai rata-rata sebesar 83,74 dengan 19 siswa (95\%) siswa yang dinyatakan tuntas dan 1 siswa dinyatakan tidak tuntas. Jadi, kelas eksperimen dinyatakan tuntas secara klasikal (kriteria ketuntasan belajar klasikal adalah $80 \%$ ), presentase kenaikan hasil belajar siswa sebesar $50 \%$.

Sedangkan pada kelas kontrol yang tidak menggunakan model pembelajaran Word Square berbasis saintifik rata-rata nilai tes sebelum diberik perlakuan pada kelas sebesar 69,50 dengan 7 siswa (35\%) yang dinyatakan tuntas dan 13 siswa (65\%) siswa dinyatakan tidak tuntas. Setelah dilakukan pembelajaran tanpa menggunakan model pembelajaran Word Square berbasis saintifik diperoleh nilai rata-rata sebesar 76 dengan 14 siswa (70\%) dinyatakan tuntas dan 6 siswa (30\%) dinyatakan tidak tuntas. Maka kelas kontrol dinyatakan tidak tuntas secara klasikal (kriteria ketuntasan belajar klasikal adalah 80\%).

Perbedaan hasil belajar siswa kelas Perbedaan hasil belajar siswa kelas kontrol dan kelas eksperimen ini dapat disebabkan karena perbedaan perlakuan pada langkah-langkah pembelajaran. Hal ini terjadi karena proses dalam model pembelajaran Word Square berbasis saintifik membentuk siswa untuk menyelesaikan masalah secara berkelompok dan dapat bertukar pikiran .

\section{KESIMPULAN}

Berdasarkan hasil penelitian yang telah dilakukan, dapat disimpulkan bahwa model pembelajaran Word Square berbasis saintifik berpengaruh terhadap hasil belajar tematik siswa kelas IV MI karangdowo. Ketuntasan belajar kelas yang menggunakan model pembelajaran Word Square berbasis saintifik mencapai 95\% (lebih dari 80\%). Sedangkan kelas yang tidak menggunakan model pembelajaran Word Square berbasis saintifik ketuntasan belajar kelasnya hanya 70\% (tidak lebih dari 80\%).

Berdasarkan simpulan di atas, saran yang dapat peneliti berikan yaitu sebagai berikut:

a) Model pembelajaran Word Square berbasis saintifik dapat digunakan sebagai salah satu alternatif pembelajaran di sekolah,

b) Perlu penelitian lebih lanjut untuk mengembangkan model pembelajaran Word Square berbasis saintifik sehingga dapat meningkatkan hasil belajar siswa lebih optimal. 


\section{DAFTAR PUSTAKA}

Arikunto, Suharsimi. 2013. Dasar-dasar Evaluasi Pendidikan. Jakarta: PT. Bumi Aksara. Depdiknas. 2013. Materi Sosialisasi Kurikulum 2013 Depdiknas:Jakarta

Dimyati dan Mujiono. 1999. Belajar Dan Pembelajaran. Jakarta:Rineka Cipta

Eko Puji Dianawati. Penggunaan Media Word Square Dalam Memotivasi Belajar Siswa , Jurnal Ilmiah “COPE”: No. 01/Tahun XVII/Mei 2013, h.23.

Soedijarto.1997. Hasil Belajar Siswa. Jakarta:Rineka Cipta. 